\title{
Study on properties of tapioca resin polymer
}

\author{
J. Jamiluddin ${ }^{*}$, J. P. Siregar'1, A. Sulaiman', K. A. A. Jalal'1, C. Tezara² \\ ${ }^{1}$ Faculty of Mechanical Engineering, Universiti Malaysia Pahang, \\ 26600 Pekan, Pahang, Malaysia \\ *Email: jamiluddin@ump.edu.my \\ Phone: +6094246225; Fax: +6094246222 \\ ${ }^{2}$ Department of Mechanical Engineering, Faculty of Science, \\ Technology, Engineering and Mathematics, INTI International University \\ 71800 Nilai, Negeri Sembilan, Malaysia
}

\begin{abstract}
Environmental, global warming, renewability, recyclability, and biodegradability issues have encouraged scientists and engineers to partially substitute petrochemical-based polymers with green polymers such as natural fibre polymer composites. A major drawback in the development of natural fiber polymer composites is the incompatibility between the matrix and fibre processing temperature, given the high temperature of the matrix based on petroleum and the low degradation temperature for natural fibre. The creation of poly lactic acid as a "green matrix" provides an alternative and a solution for the development of natural fiber polymer composites. In this work, the physical, thermal and mechanical properties of PLA tapioca resin biopolymer derived from industrial grade tapioca were reported in order to determine the optimum processing temperature. A drying process, injection moulding and hot press process are involved in sample preparation. A density test, hardness test, thermogravimetric analysis, and differential scanning calorimetry have been conducted. Afterwards, a tensile test was performed with samples at five different injection temperatures of $160^{\circ} \mathrm{C}, 165^{\circ} \mathrm{C}, 170^{\circ} \mathrm{C}, 175^{\circ} \mathrm{C}$ and $180^{\circ} \mathrm{C}$ in order to determine the optimum processing temperature. The sample at $165^{\circ} \mathrm{C}$ shows the highest result of ultimate tensile strength with $14.904 \mathrm{MPa}$, and $320.564 \mathrm{MPa}$ for the elastic modulus result. As a conclusion, $165^{\circ} \mathrm{C}$ was finalized as the optimum processing temperature of PLA tapioca resin biopolymer for future application in the research and development of natural fibre reinforced tapioca resin biopolymer composite.
\end{abstract}

Keywords: Poly lactic acid; tapioca resin; biopolymer.

\section{INTRODUCTION}

Nowadays, a growing interest has been shown by scientists and engineers in fully biobased and biodegradable polymer because of the advantages that this provides over conventional polymer material [1-3]. Recently, the development of biodegradable polymer has focused on natural fibre reinforced polymer composite material [1-9]. However, one major shortcoming of polymer material development is the manufacturing and processing temperature, where the natural fibre has a low degradation temperature while major resins available in the market such as polypropylene have higher melting temperatures [1, 4-6, 10-16]. The creation of poly lactic acid (PLA) as a "green matrix" provides an alternative and a solution for the 
development of natural fibre polymer composites. PLA is a biodegradable polyester derived from $100 \%$ annually renewable resources $[1,2,17,18]$. PLA is a thermoplastic, high-strength, high-modulus polymer that can be made from annually renewable resources to yield articles for use in either the industrial packaging field or the biocompatible medical device market $[1,2,19]$. PLA belongs to the family of aliphatic polyesters commonly made from $\alpha$-hydroxy acids, which include polyglycolic acid or polymandelic acids that are considered biodegradable and compostable. Some products of natural fibre reinforced PLA are already on the market for various applications: automotive, mobile phone or plant pots [20]. This research was carried out to study the properties of PLA tapioca resin biopolymer. It focused on the physical, thermal and mechanical properties of tapioca resin through a density test, hardness test, thermogravimetric analysis, differential scanning calorimetry and tensile test with different injection temperatures in order to get the optimum processing temperature.

\section{EXPERIMENTAL SETUP}

\section{Material}

The tapioca resin biopolymer used for this research was CMX 4413 PLA tapioca resin biopolymer manufactured by Indochine Bio Plastiques (ICBP) Sdn. Bhd, Johore. The resin was an injection grade bio-resin available in pellet or powder form for convenient use in conventional injection moulding or hot press equipment. The tapioca resin biopolymer is derived from the "Ubi Gajah" industrial grade tapioca species. This tapioca species does not belong in the food grade because it tastes very bitter. Figure 1 shows the tapioca resin in pellet form purchased for this research and Table 1 below shows the properties of CMX 4413 tapioca resin provided by the manufacturer.

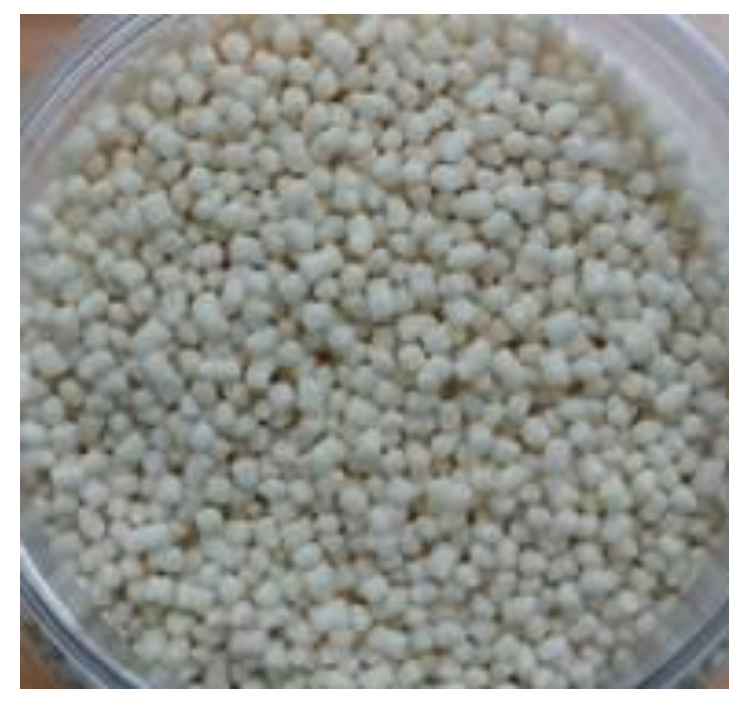

Figure 1. PLA tapioca resin biopolymer in pellet type.

\section{Preparation of Material}

The first process is for the tapioca resin to undergo a drying process in an oven at $80^{\circ} \mathrm{C}$ for 24 hours $[1,11,20]$. Then tensile test specimens were produced using the NS 20 Nissei injection moulding machine and specimen shapes based on ASTM D638 Type V [21]. Samples were produced by using 5 different injection temperatures: $160^{\circ} \mathrm{C}, 165^{\circ} \mathrm{C}$, $170^{\circ} \mathrm{C}, 180^{\circ} \mathrm{C}$ and $185^{\circ} \mathrm{C}$ with $10 \mathrm{MPa}$ pressure. Density and hardness test samples 
were produced using a compression moulding machine at $165^{\circ} \mathrm{C}$ and $10 \mathrm{MPa}$ pressure. The sample shape for density and hardness test is $200 \mathrm{~mm} \times 200 \mathrm{~mm} \times 4 \mathrm{~mm}$. However, the density test samples also underwent an additional process to cut them to $10 \mathrm{~mm} \times 10$ $\mathrm{mm}$. The vacuum oven, injection moulding and compression moulding machines used for material preparation are shown in Figure 2.

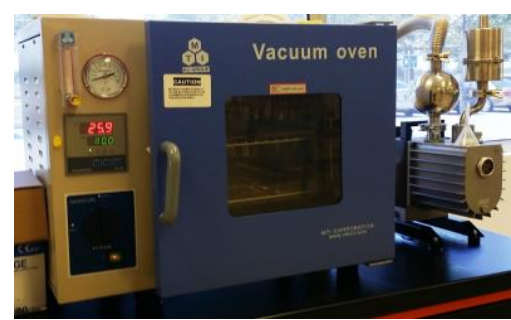

(a)

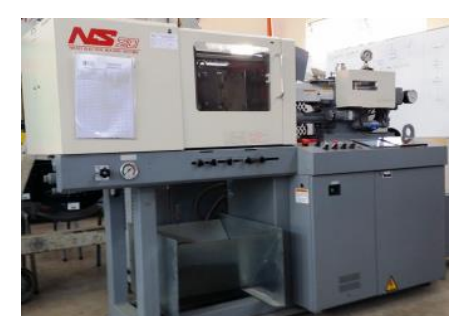

(b)

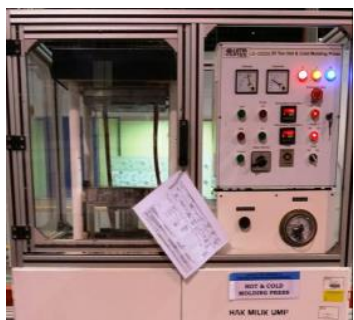

(c)

Figure 2. Experimental setup for sample preparation: (a) vacuum oven; (b) injection moulding; (c) compression molding machine.

Table 1. Properties of CMX 4413 tapioca resin prepared by the manufacturer.

\begin{tabular}{lcc}
\hline \multicolumn{1}{c}{ Properties } & Unit & Nominal value \\
\hline Density & $\mathrm{g} / \mathrm{cm}^{3}$ & 1.1 \\
Melt index & $\mathrm{g} / 10 \mathrm{~min}$ & 36 \\
Tensile strength & $\mathrm{MPa}$ & 14 \\
Tensile elongation & $\%$ & 37 \\
Flexural strength & $\mathrm{MPa}$ & 14 \\
Flexural modulus & $\mathrm{MPa}$ & 565 \\
Izod impact test & $\mathrm{J}$ & 38 \\
Hardness & $\mathrm{Shore} \mathrm{D}$ & 64 \\
Melting temperature & ${ }^{\circ} \mathrm{C}$ & 170 \\
Degradation temperature & ${ }^{\circ} \mathrm{C}$ & 185 \\
\hline
\end{tabular}

\section{Physical Properties Test}

The two types of tests which were performed to analyse the physical properties of the PLA tapioca resin biopolymer in this research were the material hardness test and density analysis. The hardness test is generally employed to determine the resistance of a material to surface indentation, scratching or marring. Softer plastic materials require a less severe scale than the R scale and are tested by test method ASTM D2240 [22]. In this research, the hardness test was carried out using a Shore D Sundoo LX-D Durometer Hardness Tester in accordance with ASTM D2240-00 [23]. The experimental setup for the hardness test is shown in Figure 3.

Density is a physical property of matter that expresses the ratio of mass to volume. The density depends on the atomic mass of the element or compound [24]. Since different substances have different densities, density measurements are very useful for the identification and characterization of different substances [25, 26]. The Adam PGW 735e density kit was used according to ASTM D792 in order to obtain the density value of the tapioca resin biopolymer [25]. Figure 4 shows the experimental setup for density measurement. 


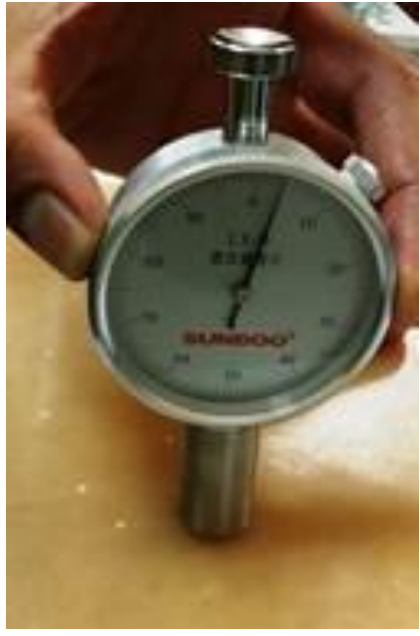

(a)

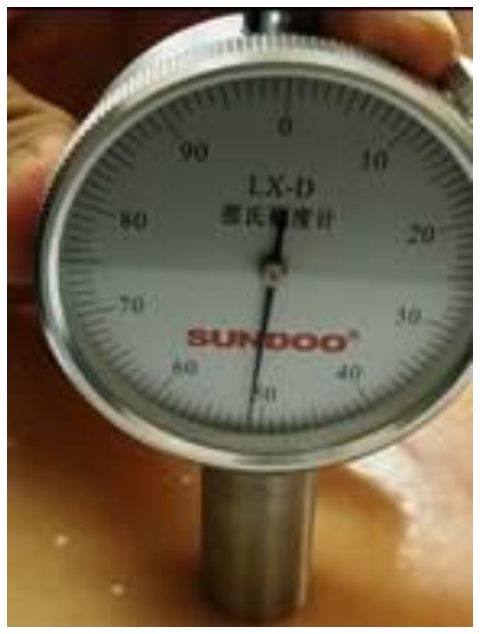

(b)

Figure 3. Hardness test experimental setup (a) before test and (b) during test.

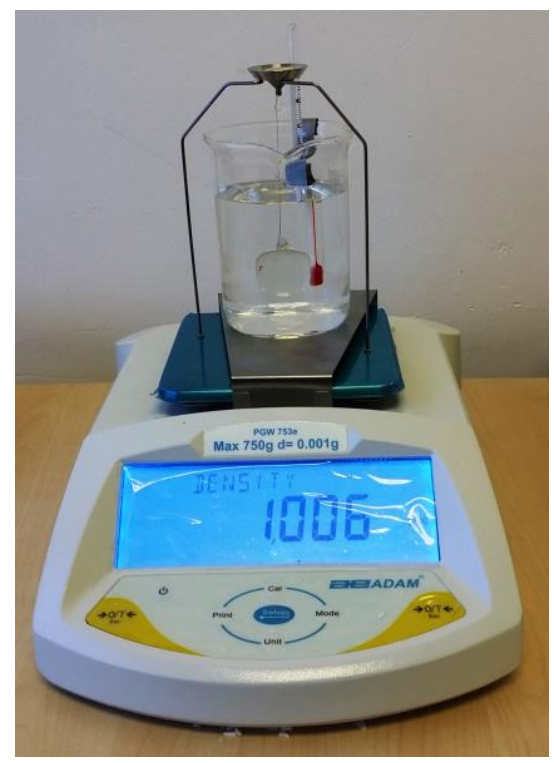

Figure 4. Density measurement setup.

\section{Thermal Properties Test}

There are two tests used to analyse the thermal properties of PLA tapioca resin biopolymer in this research, namely thermogravimetric analysis (TGA) and differential scanning calorimetry (DSC). TGA is a method of thermal analysis which can measure the changes in the physical and chemical properties of materials as a function of increasing temperature at a constant heating rate $[10,27]$. The method of TGA used in this research was according to ASTM D6370. The equipment used for TGA is TGA Q500 V6.7, where a nitrogen inert compressed gas was utilized in this research with the sample being heated from $25^{\circ} \mathrm{C}$ to $600^{\circ} \mathrm{C}$ at $10^{\circ} \mathrm{C} / \mathrm{min}$ heat rate [27]. DSC is a thermoanalytical technique in which the difference between the amount of heat required to increase the temperature of a sample and a reference is measured as a function of temperature. DSC has the capability of determining the melting point of natural fibre composites. The equipment DSC Q1000 V9.9 TA Instrument was used for DSC 
analysis in this research. The method of DSC in this research was according to ASTM $\mathrm{D} 3418$, where the sample should be heated from $25^{\circ} \mathrm{C}$ to $300^{\circ} \mathrm{C}$ at a $10^{\circ} \mathrm{C} / \mathrm{min}$ heat rate $[10,28]$. The TGA apparatus and DSC equipment are displayed in Figure 5.

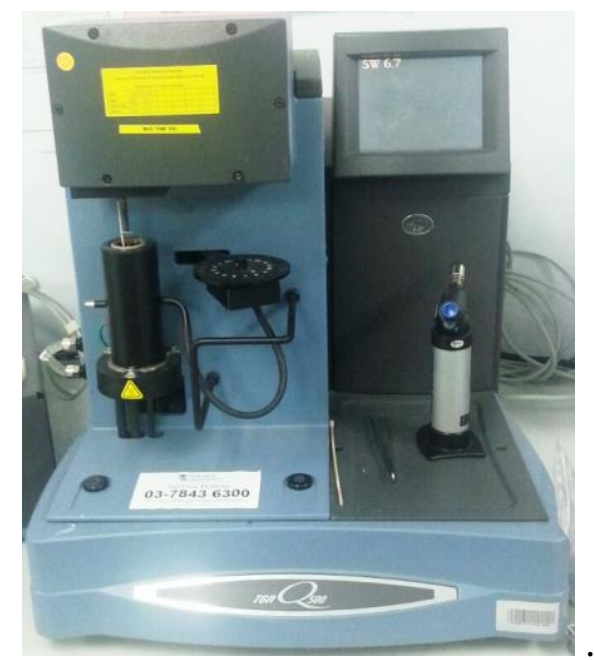

(a)

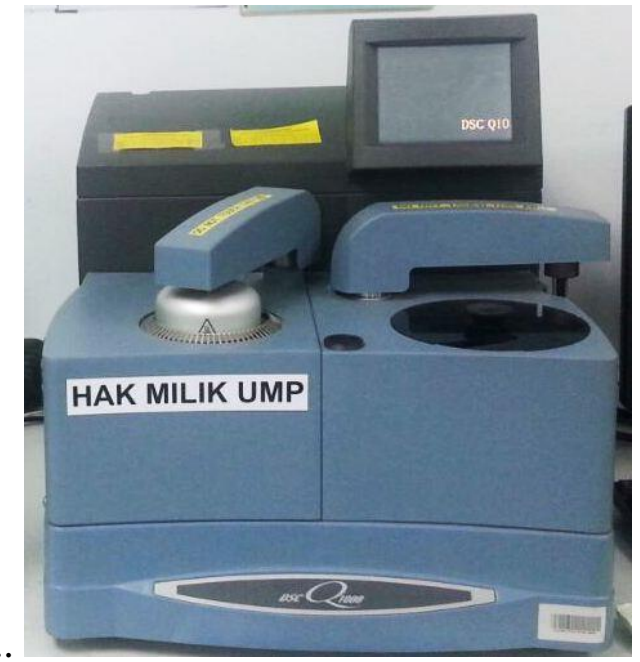

(b)

Figure 5. Experimental setup: (a) TGA Q500 V6.7; (b) DSC Q1000 V9.9 TA instrument

\section{Mechanical Properties Test}

The tensile test was conducted based on ASTM D638 using an Instron 5967 universal testing machine. A load cell of $3 \mathrm{kN}$ and crosshead speed of $1 \mathrm{~mm} / \mathrm{min}$ was used in these tests [21]. For each injection temperature, seven specimens were tested to failure while the results obtained from five specimens were collected to derive the average value. Figure 6 shows the machine used in the tensile test and the experimental setup for the tensile test.

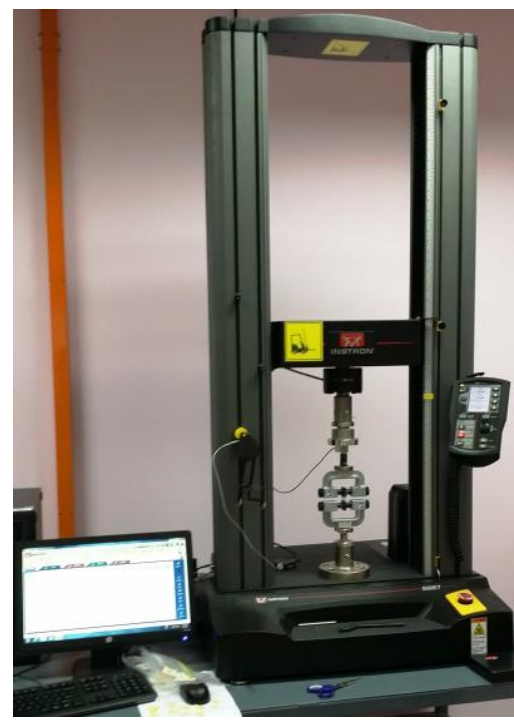

(a)

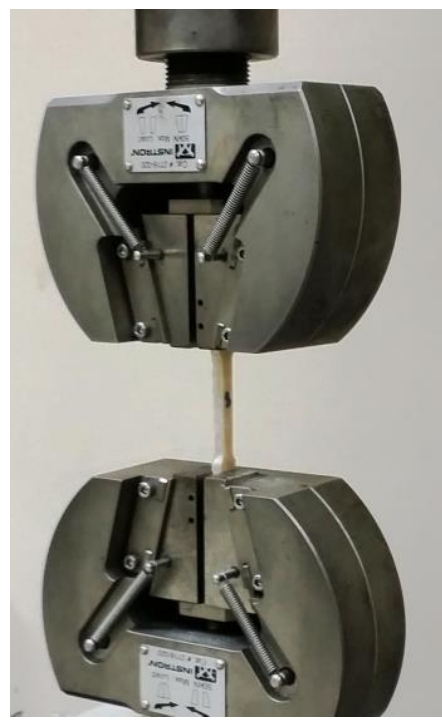

(b)

Figure 6. Experimental setup: (a) Instron 5637 universal testing machine $3 \mathrm{kN}$; (b) sample under tensile test. 


\section{RESULTS AND DISCUSSION}

\section{Thermal and Physical Properties Test Result}

The hardness test result of the PLA tapioca resin biopolymer was 60-61 Shore D and $1.005-1.006 \mathrm{~g} / \mathrm{cm}^{3}$ for its density value. A previous study on high-molecular-weight PLA by Cargill found a density value of $1.25 \mathrm{~g} / \mathrm{cm}^{3}$ and $82-88$ for Rockwell hardness. The glass transition $(\mathrm{Tg})$ of tapioca resin was at $128.76^{\circ} \mathrm{C}$, while the melting point $(\mathrm{Tm})$ was at the temperature of $165.37^{\circ} \mathrm{C}$. The DSC curve of the PLA tapioca resin biopolymer is shown in Figure 7. The findings for another type of PLA which was produced from corn starch by NatureWork, United States, showed that the glass transition and melting point were at $60.7^{\circ} \mathrm{C}$ and $125.3^{\circ} \mathrm{C}$ respectively $[1,2,19]$.

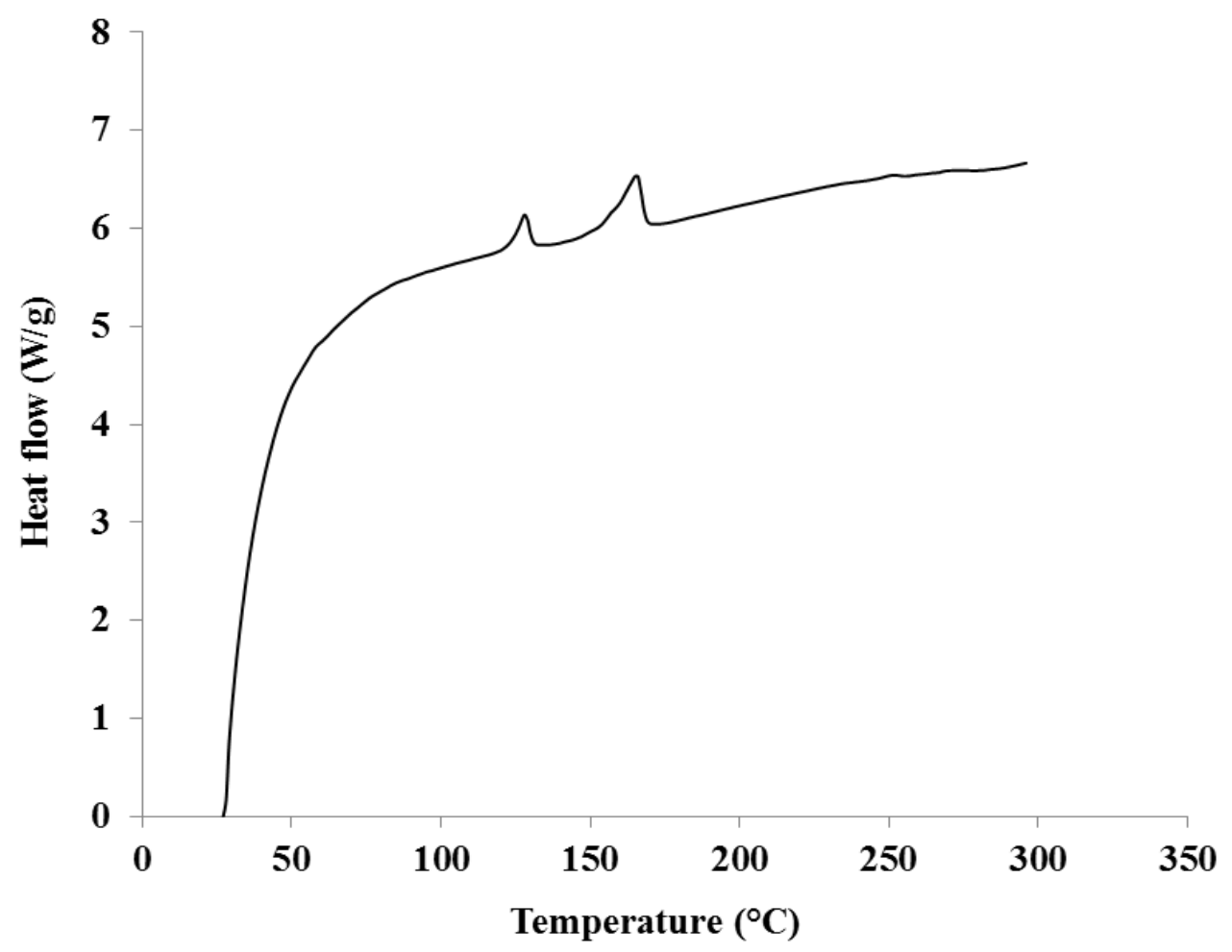

Figure 7. DSC analysis of PLA tapioca resin polymer.

Thermal degradation can be studied through TGA. The thermal decomposition of the PLA tapioca resin biopolymer under nitrogen atmosphere comprises a three-step process. Figure 8 presents the TG curve of the PLA tapioca resin biopolymer. The first step of the process, at temperatures from $28.76^{\circ} \mathrm{C}$ to $80.76^{\circ} \mathrm{C}$, showed a weight loss of $2.0 \%$. Previous studies have revealed that the loss of weight at this stage was due to the evaporation of moisture from the material $[10,17]$. The second stage of weight loss occurred at $185^{\circ} \mathrm{C}$ to $278.15^{\circ} \mathrm{C}$ with $28.64 \%$ weight loss and the third stage of the thermal decomposition of the PLA tapioca resin polymer was from $280^{\circ} \mathrm{C}$ to $385.41^{\circ} \mathrm{C}$. The overall results of the physical and thermal properties analysis of the PLA tapioca resin biopolymer are tabulated in Table 2 . Based on Table 2, the thermal properties are finalized with $165^{\circ} \mathrm{C}$ as the melting temperature and $185^{\circ} \mathrm{C}$ as the degradation temperature for the PLA tapioca resin biopolymer. 


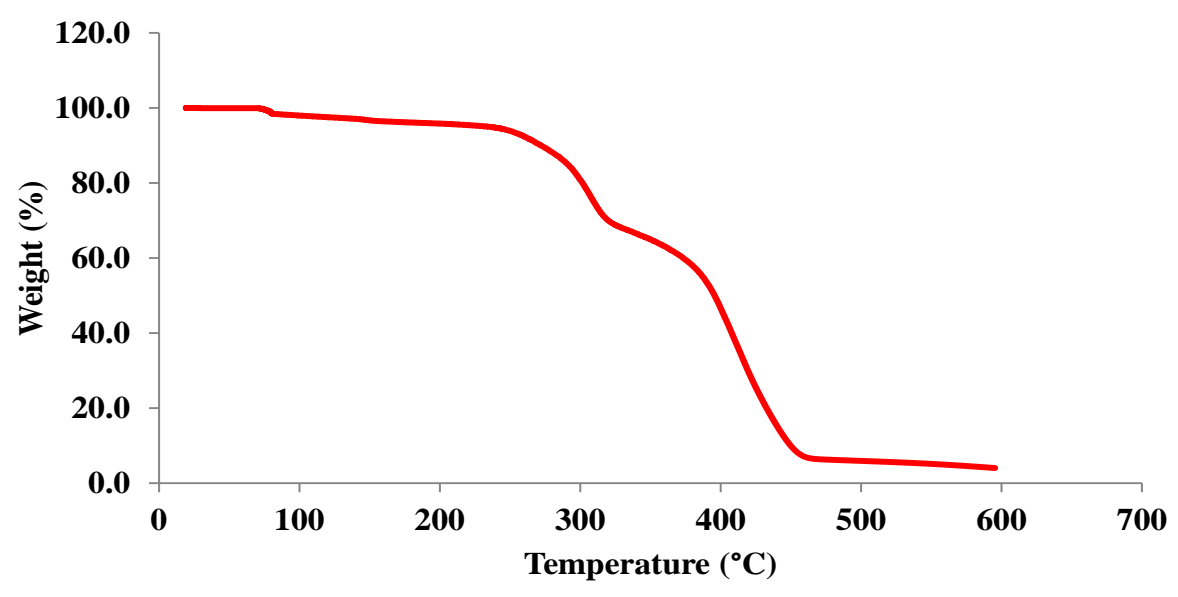

Figure 8. TG curve of PLA tapioca resin biopolymer.

Table 2. Physical and thermal properties of PLA tapioca resin biopolymer.

\begin{tabular}{lcc}
\hline \multicolumn{1}{c}{ Properties } & Unit & Tapioca Resin \\
\hline Density, $\rho$ & $\mathrm{g} / \mathrm{cm}^{3}$ & $1.005 \sim 1.006$ \\
Hardness & Shore D & $60 \sim 61$ \\
Melting temperature, Tm & ${ }^{\circ} \mathrm{C}$ & 165 \\
Degradation temperature & ${ }^{\circ} \mathrm{C}$ & 185 \\
\hline
\end{tabular}

\section{Mechanical Properties Test Result}

In this research, tensile test specimens were produced by using an injection molding machine with six different injection temperatures: $160^{\circ} \mathrm{C}, 165^{\circ} \mathrm{C}, 170^{\circ} \mathrm{C}, 175^{\circ} \mathrm{C}, 180^{\circ} \mathrm{C}$ and $185^{\circ} \mathrm{C}$. The injection temperature was set based on the TGA and DSC results. Figure 9 shows the tensile test specimens with different injection temperatures.

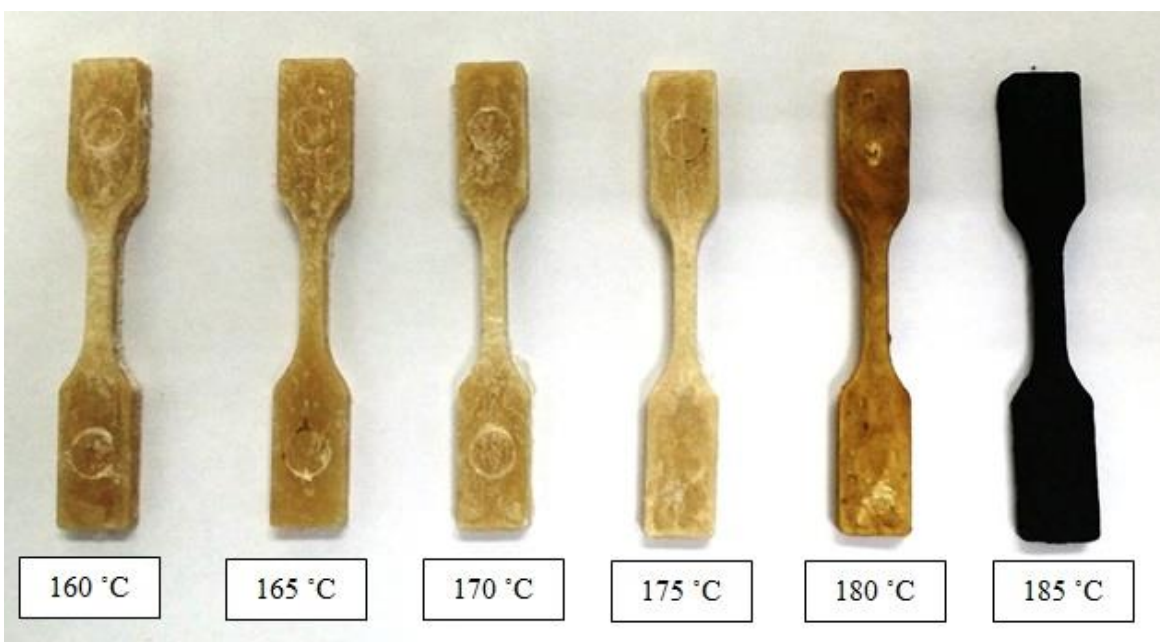

Figure 9. PLA tapioca resin biopolymer tensile test samples produced by injection moulding method. 
The $185^{\circ} \mathrm{C}$ sample can still be produced using injection moulding but has the appearance of looking burnt, has a charred smell and with limitation in quantity. These conditions prove the DSC test result that $185^{\circ} \mathrm{C}$ is the degradation temperature for PLA tapioca resin. Therefore, only five types of samples with temperatures of $160^{\circ} \mathrm{C}, 165^{\circ} \mathrm{C}$, $170^{\circ} \mathrm{C}, 175^{\circ} \mathrm{C}$ and $180^{\circ} \mathrm{C}$ are taken into account for the study. The comparative results for the ultimate tensile strength for samples at different injection temperatures are shown in Figure 10, with the mean value of ultimate tensile strength for each sample displayed in a graph. Based on Figure 10 , the sample at $165^{\circ} \mathrm{C}$ recorded the highest ultimate tensile strength value of 14.904 MPa.

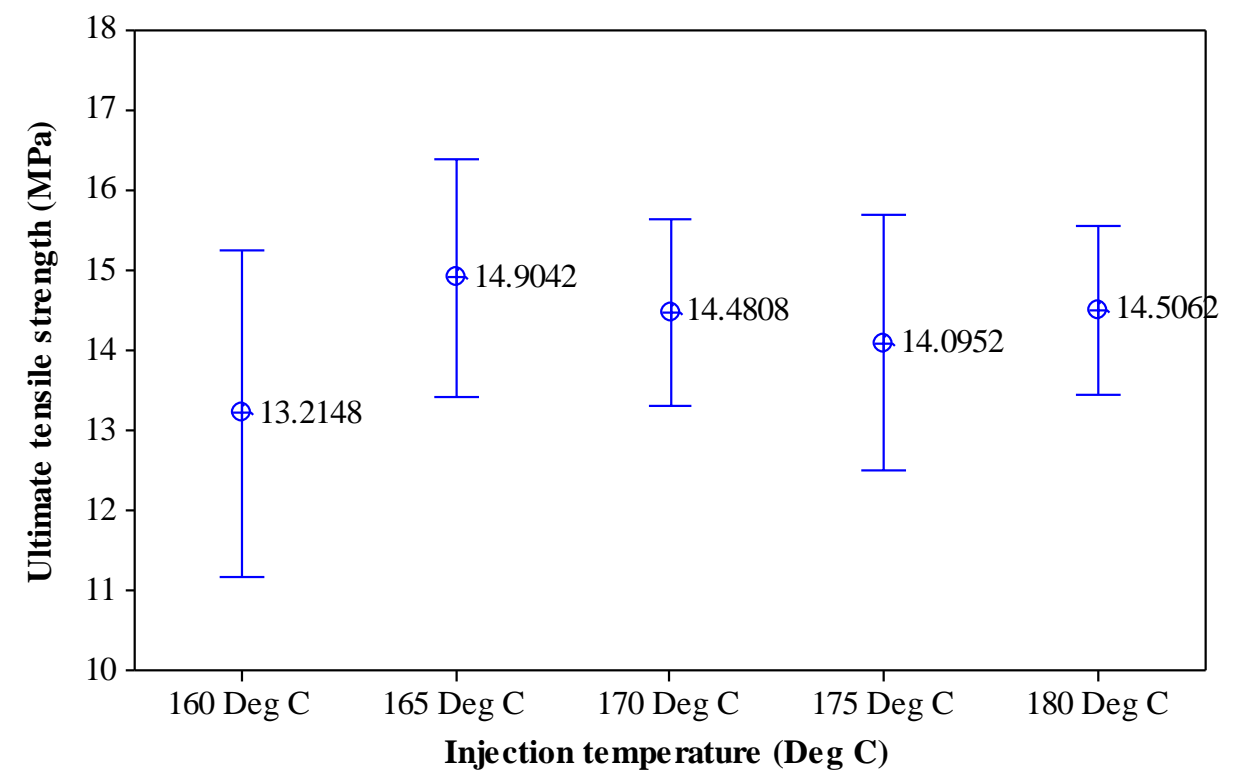

Figure 10. Comparison of ultimate tensile strength for different injection temperatures for PLA tapioca samples.

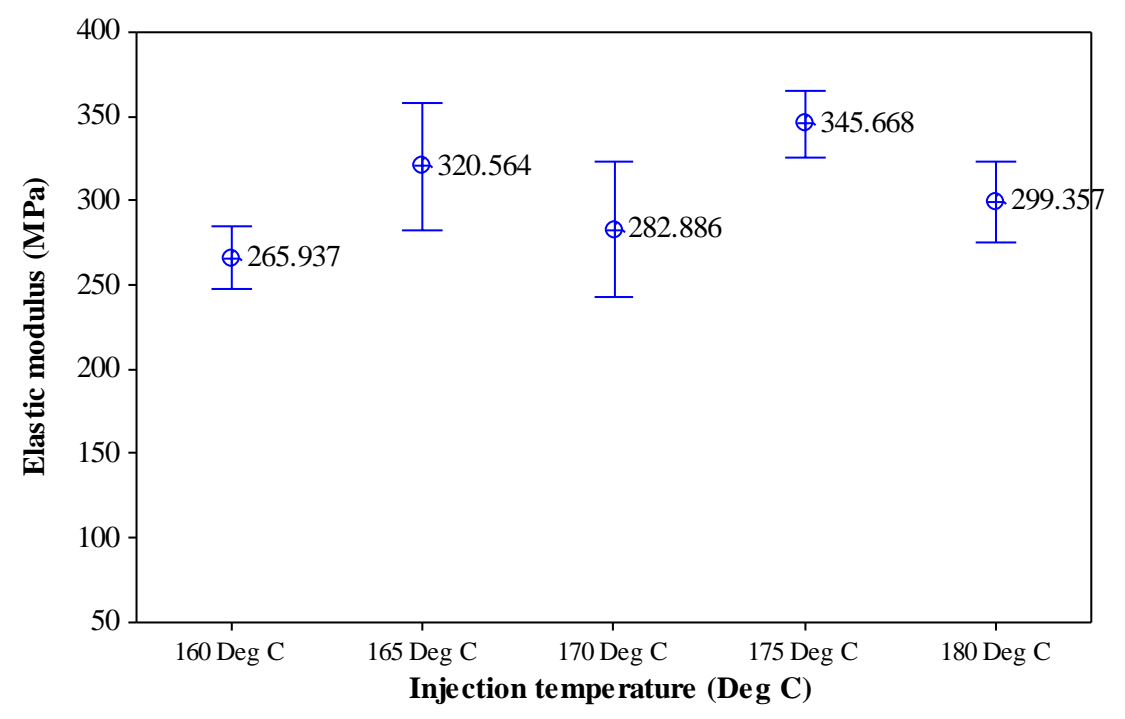

Figure 11. Comparison of elastic modulus for different injection temperatures for PLA tapioca samples. 
Meanwhile, comparison of the results for the elastic modulus is shown in Figure 11. However, based on Figure 11, it is shown that there are no significant differences in the elastic modulus values for the injection temperatures from $165^{\circ} \mathrm{C}$ to $180^{\circ} \mathrm{C}$. In conclusion, the temperature of $165^{\circ} \mathrm{C}$ recorded is as the optimum processing temperature, as the highest ultimate tensile stress value is produced by this sample. Figure 12 shows the stress-strain curves of five samples from the $165^{\circ} \mathrm{C}$ injection temperature and the overall mechanical properties of the PLA tapioca resin biopolymer samples shown in Table 3. Based on Figure 12 and Table 3, the five samples from the $165^{\circ} \mathrm{C}$ injection temperature show the same pattern of stress-strain curve with a standard deviation of 1.19 for the ultimate tensile strength value. All the samples failed between 1.1 minute and 1.2 minute, which is within the specification of ASTM D63810 [21]. Table 4 shows a comparison of ultimate tensile strength and melting temperature of PLA tapioca resin and other available resins in the market.

Table 3. Mechanical properties of PLA tapioca resin biopolymer.

\begin{tabular}{cccccc}
\hline Specimen & $\begin{array}{c}\text { Modulus } \\
{[\mathrm{MPa}]}\end{array}$ & $\begin{array}{c}\text { Ultimate tensile } \\
\text { strength } \\
{[\mathrm{MPa}]}\end{array}$ & $\begin{array}{c}\text { Tensile strain } \\
\text { at break } \\
{[\%]}\end{array}$ & $\begin{array}{c}\text { Time at } \\
\text { break } \\
{[\mathrm{min}]}\end{array}$ \\
\hline 1 & $165^{\circ} \mathrm{C}(1)$ & 346.650 & 15.060 & 11.855 & 1.1 \\
2 & $165^{\circ} \mathrm{C}(2)$ & 331.407 & 15.552 & 12.065 & 1.2 \\
3 & $165^{\circ} \mathrm{C}(3)$ & 325.900 & 15.932 & 11.692 & 1.1 \\
4 & $165^{\circ} \mathrm{C}(4)$ & 267.973 & 15.113 & 13.077 & 1.2 \\
5 & $165^{\circ} \mathrm{C}(5)$ & 330.890 & 12.864 & 12.422 & 1.2 \\
\hline $\begin{array}{c}\text { Mean } \\
\text { Standard } \\
\text { deviation }\end{array}$ & & 320.564 & 14.904 & 12.222 & 1.2 \\
\hline
\end{tabular}

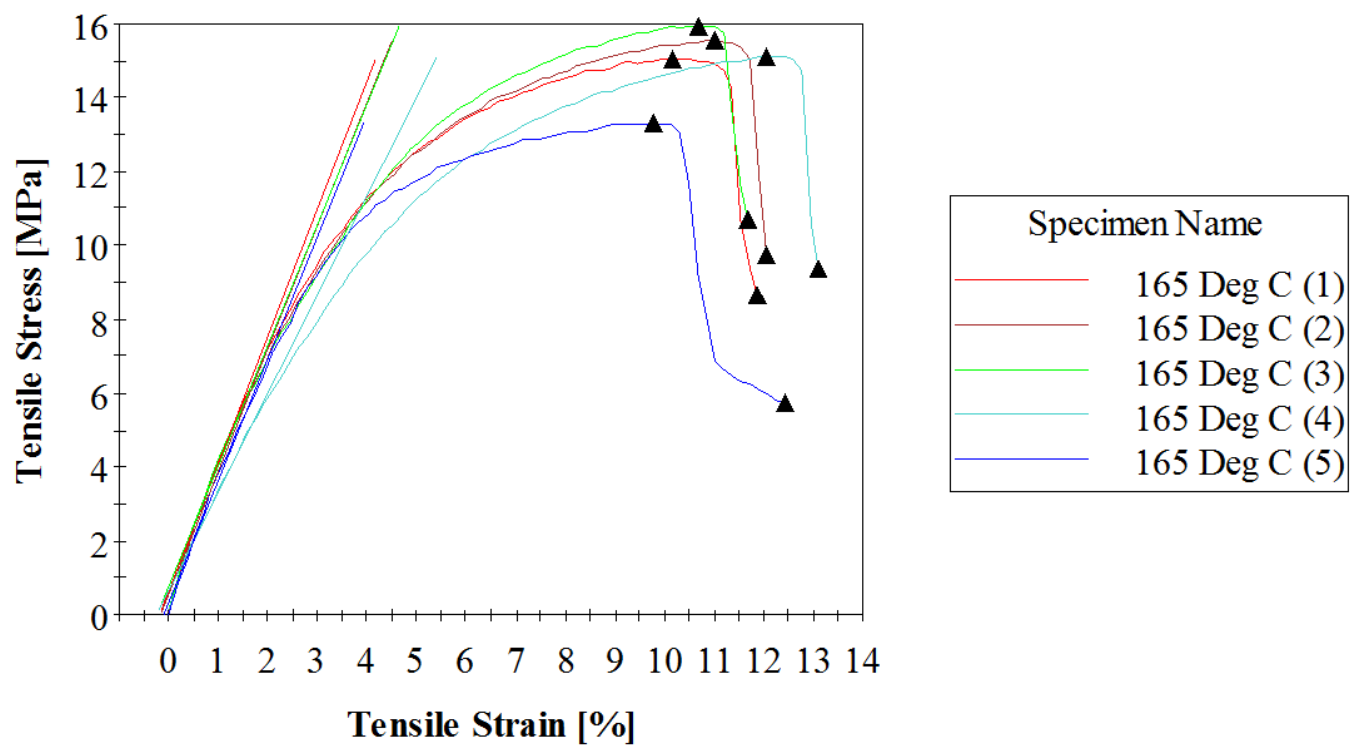

Figure 12. Stress-strain curve of PLA tapioca resin biopolymer. 
Table 4. Comparison of ultimate tensile strength and melting temperature of PLA tapioca resin and other resins [29-34].

\begin{tabular}{|c|c|c|}
\hline Resin & $\begin{array}{c}\text { Melting temperature, } \\
\mathrm{T}_{\mathrm{m}}\left({ }^{\circ} \mathrm{C}\right)\end{array}$ & $\begin{array}{c}\text { Ultimate tensile } \\
\text { strength, UTS (MPa) }\end{array}$ \\
\hline PLA tapioca resin, ICBP & 165 & 14.904 \\
\hline PLA corn starch, Nature Work, USA & 200 & 58.9 \\
\hline Polyethylene & 210 & 30 \\
\hline HDPE & 190 & 23.9 \\
\hline Nylon 6 & 221 & 44 \\
\hline $\mathrm{ABS}$ & 190 & 29.3 \\
\hline
\end{tabular}

Based on Table 4, the major shortcoming of the PLA tapioca resin is its low tensile strength compared with petroleum-based polymer resin, and also its lower tensile strength compared with PLA corn starch from NatureWork, USA. However, the lower melting temperature of tapioca resin provides an opportunity for the PLA to be improved by natural fibre reinforcement and the material is still able to maintain its edge as a degradable material.

\section{CONCLUSIONS}

The mechanical properties of CMX 4413 tapioca resin biopolymer have been investigated. Based on thermogravimetric analysis and differential scanning calorimetry, the optimum processing temperature of tapioca resin biopolymer was finalized with $165^{\circ} \mathrm{C}$ as the melting temperature and $185^{\circ} \mathrm{C}$ as the degradation temperature. Generally, the majority of natural fibres have processing temperatures less than $200^{\circ} \mathrm{C}$. By virtue of having a processing temperature between $165^{\circ} \mathrm{C}$ and $185^{\circ} \mathrm{C}$, tapioca resin PLA can provide a solution for the issue of the incompatibility between the matrix and natural fibre processing temperatures. In conclusion, a temperature of $165^{\circ} \mathrm{C}$ is recorded as the optimum processing temperature due to the highest ultimate tensile stress value produced by this sample, which is $14.904 \mathrm{MPa}$. The physical, thermal and mechanical properties recorded in this research mean that PLA tapioca resin biopolymer can be a catalyst for the development of fully bio-based and biodegradable polymer composites for engineering applications as a substitute for petrochemical-based polymers.

\section{ACKNOWLEDGEMENTS}

The authors would like to be obliged to Universiti Malaysia Pahang for providing laboratory facilities and financial assistance under project no. RDU140120.

\section{REFERENCES}

[1] Du Y, Wu T, Yan N, Kortschot MT, Farnood R. Fabrication and characterization of fully biodegradable natural fiber-reinforced poly (lactic acid) composites. Composites Part B: Engineering. 2014;56:717-23.

[2] Vink ET, Rabago KR, Glassner DA, Gruber PR. Applications of life cycle assessment to NatureWorks ${ }^{\mathrm{TM}}$ polylactide (PLA) production. Polymer Degradation and stability. 2003;80:403-19. 
[3] Bachtiar D, Sapuan SM, Hamdan MM. Flexural properties of alkaline treated sugar palm fibre reinforced epoxy composites. International Journal of Automotive and Mechanical Engineering. 2010;1:79-90.

[4] Sapuan SM Mohamed, AR, Siregar JP, Ishak MR. Pineapple leaf fibers and PALF-Reinforced polymer composites. Cellulose Fibers: Bio- and Nano Polymer Composites: Springer-Verlag Berlin Heidelberg; 2011. p. 325-43.

[5] Shalwan A, Yousif BF. In State of Art: Mechanical and tribological behaviour of polymeric composites based on natural fibres. Materials \& Design. 2013;48:1424.

[6] Roslan SAH Hassan MZ, Rasid ZA, Zaki SA, Daud Y, Aziz S, Sarip S, Ismail Z. Mechanical properties of bamboo reinforced epoxy sandwich structure composites. International Journal of Automotive and Mechanical Engineering. 2015;12:2882-92.

[7] Zakaria I, Michael Z, Mohamed WANW, Mamat AMI, Azmi WH, Mamat R, et al. A review of nanofluid adoption in polymer electrolyte membrane (PEM) fuel cells as an alternative coolant. Journal of Mechanical Engineering and Sciences. 2015;8:1351-66.

[8] Taufik RS, Adibah M NF, Muhamad MR, Hasib H. Feasibility Study of Natural Fiber Composite Material for Engineering Application. Journal of Mechanical Engineering and Sciences. 2014;6:940-8.

[9] Ab Latif N, M. Rus AZ. Vibration Transmissibility Study of High Density Solid Waste Biopolymer Foam. Journal of Mechanical Engineering and Sciences. 2014;6:772-81.

[10] Siregar JP, Salit MS, Rahman MZA, Dahlan KZHM. Thermogravimetric Analysis (TGA) and Differential Scanning Calometric (DSC) Analysis of Pineapple Leaf Fibre (PALF) Reinforced High Impact Polystyrene (HIPS) Composites. Pertanika Jour-nal of Science and Technology. 2011;19:161-70.

[11] Liu W, Misra M, Askeland P, Drzal LT, Mohanty AK. 'Green'composites from soy based plastic and pineapple leaf fiber: fabrication and properties evaluation. Polymer. 2005;46:2710-21.

[12] Westman MP SGL, Fifield LS, Kalentzis TA, Simmons KL. Natural fiber composites: A review. US Department of Energy under Contract DE-AC0576LD01830. 2010.

[13] Nanthaya Kengkhetkit TA. A new approach to "Greening" plastic composites using pineapple leaf waste for performance and cost effectiveness. Materials and Design 2014;55 292-9.

[14] Lingenthiren KK, Siregar JP, Rahman MM, Thiruselvam S and Ghazali Z. Review of Natural Fibers Mechanical Properties. Bothalia Journal. 2014;3:45.

[15] Azrin Hani AR, Shaari MF, Mohd Radzuan NS, Hashim MS,, Ahmad R, Mariatti M. Analysis of woven natural fiber fabrics prepared using self-designed handloom. International Journal of Automotive and Mechanical Engineering. 2013;8:1197-206.

[16] Kishor Kumar K, Ramesh Babu P, Raja Narender Reddy K. Evaluation of flexural and tensile properties of short kenaf fiber reinforced green composites. International Journal of Advanced Mechanical Engineering. 2014;4:371-80.

[17] Azwa Z, Yousif B, Manalo A, Karunasena W. A review on the degradability of polymeric composites based on natural fibres. Materials \& Design. 2013;47:42442. 
[18] Erwin T.H. Vinka, Karl R. Ra' bagob,David A. Glassnerb,Patrick R. Gruberb. Applications of life cycle assessment to NatureWorks polylactide (PLA) production. Polymer Degradation and Stability 2003;80 403-19.

[19] Gruber P, O'Brien M. Polylactides "Natureworks ${ }^{\circledR}$ PLA". Biopolymers Online. 2005.

[20] Garlotta D. A Literature Review of Poly(Lactic Acis). Journal of Polymers and the Environmet. 2001;9:22.

[21] International A. ASTM D 638-03 Standard Test Method for Tensile Properties of Plastics. American Society of Testing and Material. 2003.

[22] International A. ASTM D 785-03 Standard test method for Rockwell hardness of plastics and electrical insulating materials. American Society of Testing and Material. 2003.

[23] International A. ASTM D 2240-00 Standard test method for rubber property Durometer Hardness. American Society of Testing and Material. 2000.

[24] Siregar JP, Sapuan S, Rahman M, Zaman H. The effect of alkali treatment on the mechanical properties of short pineapple leaf fibre (PALF) reinforced high impact polystyrene (HIPS) composites. J of Food, Agriculture \& Environment. 2010;8:1103-8.

[25] International A. ASTM D 1505-03 Standard Test Method for Density of Plastics by the Density-Gradient Technique. American Society of Testing and Material. 2003.

[26] Kažys R, Rekuvienė R. Viscosity and density measurement methods for polymer melts. Ultragarsas" Ultrasound". 2012;66:20-5.

[27] International A. ASTM D 6370-99 (Reapproved 2003) Standard Test Method for Rubber-Compositional Analysis by Thermogravimetry (TGA). American Society of Testing and Material. 2003.

[28] International A. ASTM D 3418-03 Standard test method for transition temperatures of polymers by differential scanning calorimet. American Society of Testing and Material. 2003.

[29] Mehdi Jonoobi JH, Aji P. Mathewb, Kristiina Oksmanb,. Mechanical properties of cellulose nanofiber (CNF) reinforced polylactic acid (PLA) prepared by twin screw extrusion. Composites Science and Technology. 2010;70 1742-7.

[30] Zhu W, Yan C, Shi Y, Wen S, Liu J, Shi Y. Investigation into mechanical and microstructural properties of polypropylene manufactured by selective laser sintering in comparison with injection molding counterparts. Materials \& Design. 2015;82:37-45.

[31] Liang JZ, Du Q, Tsui GC-P, Tang C-Y. Tensile properties of graphene nanoplatelets reinforced polypropylene composites. Composites Part B: Engineering. 2016;95:166-71.

[32] Wang X, Bradford PD, Liu W, Zhao H, Inoue Y, Maria J-P, et al. Mechanical and electrical property improvement in CNT/Nylon composites through drawing and stretching. Composites Science and Technology. 2011;71:1677-83.

[33] Mao ND, Thanh TD, Thuong NT, Grillet A-C, Kim NH, Lee JH. Enhanced mechanical and thermal properties of recycled ABS/nitrile rubber/nanofil N15 nanocomposites. Composites Part B: Engineering. 2016;93:280-8.

[34] Su J, Zhang J. Comparison of rheological, mechanical, electrical properties of HDPE filled with $\mathrm{BaTiO}_{3}$ with different polar surface tension. Applied Surface Science (In press), doi:10.1016/j.apsusc.2015.10.156. 